\author{
Anna CZARnecka, Magdalena ZielińsKa
}

Zakład Neurotoksykologii Instytut Medycyny Doświadczalnej i Klinicznej im. M. Mossakowskiego PAN

Pawińskiego 5, 02-106 Warszawa

E-mail: aczarnecka@imdik.pan.pl

\title{
PO CO NAM KWASY ŻÓŁCIOWE W MÓZGU?*
}

\section{WPROWADZENIE}

Kwasy żółciowe (KŻ), będące głównym składnikiem żółci, są syntetyzowane w watrobie jako końcowy produkt metabolizmu cholesterolu. Warunkuja prawidłowe trawienie i wchłanianie tłuszczów oraz witamin rozpuszczalnych w tłuszczach (A, D, E, K). Ta rola KŻ jest powszechnie znana i utrwalona w ogólnej świadomości. Wyróżniająca je cechą jest zdolność do działania przez odmienne mechanizmy molekularne zarówno niereceptorowe, jak emulgacja lipidów, działanie na błony komórkowe, działanie allosteryczne (modyfikacja funkcji różnych białek), jak i przez własne, swoiste receptory bezpośrednio modyfikujące szereg szlaków sygnałowych (HoFMANN 2009). Najnowsze odkrycia udowodniły, że receptory $\mathrm{KŻ} \mathrm{znajdują} \mathrm{się} \mathrm{również} \mathrm{w}$ ośrodkowym układzie nerwowym (OUN), co otworzyło nowe perspektywy przed badaniem znaczenia KŻ jako cząsteczek mogących wpływać na funkcjonowanie mózgu.

\section{SYNTEZA I METABOLIZM KWASÓW ŻÓŁCIOWYCH}

KŻ zostały po raz pierwszy opisane $\mathrm{w}$ 1848 r., po wyizolowaniu kwasu cholowego (CA) z żółci wołu (DE AGUIAR VALLim i współaut. 2013). Następnie zidentyfikowano kolejne KŻ, w tym: kwas litocholowy (LCA), chenodeoksycholowy (CDCA), ursodeoksycholowy (UDCA) i murycholowy (MCA), odpowiednio w żółci wołu, gęsi, niedźwiedzia i gryzoni, co dokładnie omówił Heinrich Wieland w swoim wystapieniu po otrzymaniu nagrody Nobla w dziedzinie chemii w 1928 r. (WIELAND 1928). Biosynteza KŻ zachodzi w hepatocytach wattroby na drodze klasycznej (szlak obojętny) lub alternatywnej (szlak kwasowy). W procesie przekształcania cholesterolu do KŻ bierze udział 17 enzymów; w głównej mierze sa to białka należące do rodziny cytochromu P450. Szlaki te różnią się głównie zaangażowaniem odmiennych enzymów. KŻ zsyntetyzowane de novo w watrobie określamy pierwotnymi i u człowieka zaliczamy do nich CA i CDCA. Z hepatocytów KŻ sa wydzielane do przewodów żółciowych przy udziale swoistych transporterów (ang. bile salt export pomp, BSEP; oraz ang. multidrug resistance-associated protein 2, MRP2). $\mathrm{KŻ} \mathrm{u} \mathrm{człowieka} \mathrm{sa} \mathrm{magazynowane} \mathrm{w} \mathrm{pęche-}$ rzyku żółciowym i uwalniane do światła jelita cienkiego po spożyciu posiłku. Tam moga zostać przekształcone we wtórne KŻ: kwas deoksycholowy (DCA) i LCA, przy udziale bakterii tworzących mikroflorę jelit. W żółci KŻ występuja jako amidy aminokwasów tauryny i glicyny (u człowieka dominuja te związanego $\mathrm{z}$ glicyna, a $\mathrm{u}$ gryzoni $\mathrm{z}$ tauryna). Dla odróżnienia od „wolnych” KŻ zaproponowano nazywanie ich solami żółciowymi. Wielkość puli KŻ u człowieka wynosi między 2-4 g (DE AGUiar VALLim i współaut. 2013). Większość tej puli jest aktywnie reabsorbowana przez enterocyty (komórki absorpcyjne kosmków jelitowych) i krąży w zamkniętym obiegu pomiędzy jelitem a wątroba (krażenie jelitowo-wattrobowe, ang. enterohepatic cir-

Słowa kluczowe: bariera krew-mózg, cholesterol, choroby neurodegeneracyjne, encefalopatia wątrobowa, krążenie jelitowo-wątrobowe, kwasy żółciowe, neuron

*Praca powstała w wyniku realizacji projektu badawczego o nr 2017/01/X/NZ4/00110 finansowanego ze środków Narodowego Centrum Nauki. 
culation). Proces reabsorbcji KŻ jest bardzo skuteczny i w jego wyniku 95\% KŻ zostaje wchłoniętych i $z$ krwia transportowanych $z$ powrotem do watroby, a pozostałe 5\% ulega wydaleniu $z$ kałem. Na skutek niepełnego wychwytu zwrotnego KZे w hepatocytach, część $z$ nich $(<10 \%)$ przedostaje się do krążenia obwodowego i jest wykrywana w niewielkiej ilości w surowicy (MERTENs i współaut. 2017).

\section{SZLAK MÓZGOWY SYNTEZY KŻ (SZLAK USUWANIA CHOLESTEROLU W NEURONACH)}

Spośród wszystkich narządów ciała, mózg jest najbardziej bogaty w cholesterol i zawiera piąta część całej jego puli dostępnej w organizmie (BJÖRKHEM i MEANEY 2004). Z tej części, 70-80\% tworzy osłonki mielinowe włókien nerwowych, a reszta jest składnikiem budulcowym błon komórkowych neuronów i astrocytów (ZHANG i LIU 2015). Przy zachowanej funkcjonalności bariery krew-mózg, metabolizm cholesterolu w mózgu jest całkowicie oddzielony od obwodowego. Większość cholesterolu w mózgu akumuluje się w okresie okołoporodowym i wczesnego dorastania, co koreluje $z$ formowaniem się osłonek mielinowych. Po mielinizacji obrót cholesterolu w dorosłym mózgu jest utrzymany na bardzo niskim poziomie, $z$ szacowanym okresem półtrwania od 6 miesięcy do 5 lat, co mocno kontrastuje $z$ danymi pochodzącymi $z$ osocza, gdzie okres półtrwania wynosi zaledwie kilka dni (ZHANG i LIU 2015). Neurony posiadaja specyficzna odmianę hydroksylazy cholesterolowej - CYP46A1, która przeprowadza przemianę cholesterolu na drodze 24(S)-hydroksylacji, a następnie 7a-hydroksylacji $z$ udziałem enzymu CYP39A1. Mimo że CYP39A1 uznawano wcześniej za enzym specyficzny dla wattroby, jego ekspresję odkryto również w komórkach siatkówki oka i potwierdzono przez obecność specyficznego mRNA w mózgu, co pozwala

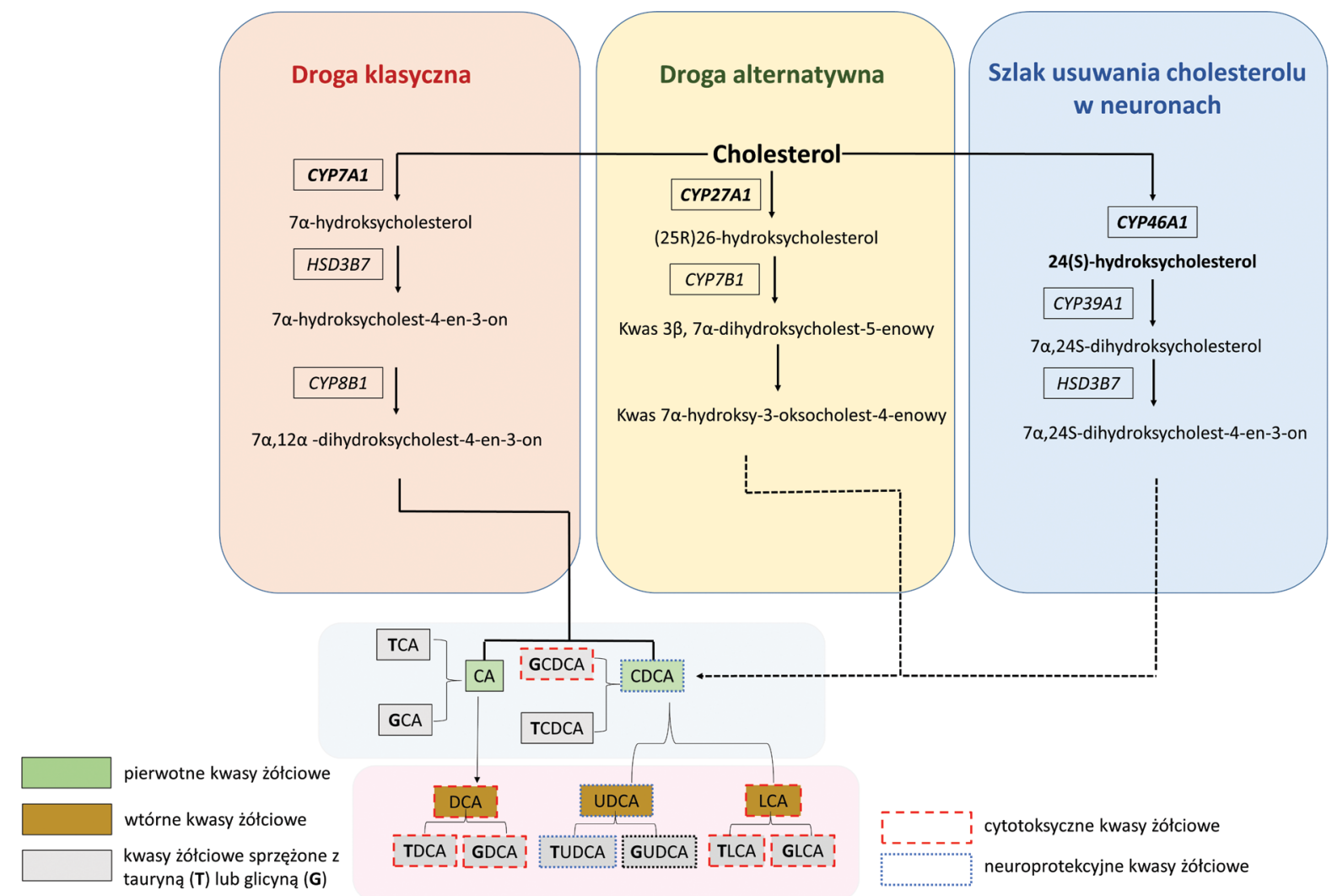

Ryc. 1. Etapy biosyntezy kwasów żółciowych u człowieka.

Klasyczny szlak przebiega w wątrobie i odpowiada za większość syntezy KŻ. Szlak ten jest inicjowany przez enzym 7a-hydroksylazę cholesterolu (kodowana przez CYP7A1) i prowadzi do powstawania pierwotnych KŻ, kwasu cholowego (CA) i kwasu chenodeoksycholowego (CDCA). Alternatywny szlak syntezy KŻ zachodzi także w innych tkankach poza watroba. Ten szlak jest inicjowany przez enzym CYP27A1 prowadzac do powstania CDCA. Ostatni szlak ma miejsce w mózgu i uważa się, że jego główną rolą jest usuwanie cholesterolu z neuronów. Pierwotne kwasy żółciowe są sprzęgane $w$ wątrobie $z$ aminokwasami glicyną ( $G$, głównie $u$ człowieka) lub tauryną (T, głównie u gryzoni). Tworzenie wtórnych kwasów żółciowych zachodzi w jelicie $z$ udziałem flory jelitowej, które po reabsorbcji do wątroby moga również zostać sprzężone $z$ glicyną i tauryną. 
przypuszczać, że może to być szlak aktywnej syntezy KŻ w OUN. Współczesne dane wskazują jednak, że główną rolą enzymu CYP46A1 jest utrzymanie homeostazy cholesterolu w mózgu przez jego przekształcanie do formy 24(S)-hydroksycholesterolu, która może być usuwana przez barierę krew-mózg do krążenia obwodowego (NoRLIN i współaut. 2000).

Klasyczny i alternatywny szlak syntezy KŻ (także jego fragment zachodzacy w mózgu) zostały przedstawione na Ryc. 1.

Niezależnie od syntezy KŹ, zaburzenia homeostazy cholesterolu w mózgu leżą u podłoża kilku schorzeń neurologicznych. Zaliczamy do nich m.in.: zespół Smitha-Lemliego-Opitza, który jest związany $z$ niedoborem cholesterolu w mózgu, oraz chorobę Niemanna i Picka typu C, w przebiegu której dochodzi do jego akumulacji (BJÖRKHEM i MEANEY 2004). Zaburzenia w metabolizmie cholesterolu towarzyszą też chorobom neurodegeneracyjnym takim jak: choroba Alzheimera, Parkinsona czy Huntingtona (ZHANG i LIU 2015).

\section{KWASY ŻÓECIOWE W OUN}

Pierwsze doniesienia o obecności KŻ w OUN zawdzięczamy badaniom nad uszkodzeniem wątroby prowadzacym do wystąpienia encefalopatii wątrobowej, ciężkiego złożonego zespołu neurologiczno-psychiatrycznego. Wykazano, zarówno u chorych pacjentów, jak i w modelach $z$ użyciem gryzoni, że w następstwie niewydolności watroby dochodzi (i) do podniesienia poziomu KŻ w OUN (płyn mózgowo-rdzeniowy i tkanki mózgu) umożliwiającego ich detekcje, oraz (ii) do zmiany profilu jakościowego KŻ na neurotoksyczny (BRON i współaut. 1977, TRIPODI i współaut. 2012). W kolejnych latach wykazano, że KŻ przechodzą do mózgu $z$ krążenia obwodowego na skutek zmian w przepuszczalności bariery krew-mózg (QUINN i DEMORROW 2012, QUINN i współaut. 2014, MCMILLIN i współaut. 2016). Dopiero później, dzięki rozwojowi bardziej czułych metod detekcji udowodniono, że wszystkie typy KŹ (pierwotne, wtórne i sprzężone $z$ aminokwasami) sa obecne w mózgu nie tylko w warunkach patologicznych, ale również u zdrowych ludzi i gryzoni (MANO i współaut. 2004, PAN i współaut. 2017). W ostatnim czasie pojawiaja się coraz liczniej prace wykorzystujące strategie metabolomicznego profilowania typów KZ̈ w różnych tkankach organizmu, w tym również w mózgu. Wykazano, że w warunkach encefalopatii watrobowej (WEISS i współaut. 2016) i choroby Alzheimera (MAHMOUDIANDEHKORDI i współaut. 2019) dochodzi do zmian zarówno ilościowych, jak również, co wydaje się istotniejsze, jakościowych profilu (rodzajów) KŻ w OUN. Badania te pozwoliły na zidentyfikowanie 20 typów KŻ w mózgu, w tym 9 niesprzężonych i 11 sprzężonych $z$ glicyna lub tauryną (ZHENG i współaut. 2016).

Wciąz nie można $z$ cała pewnościa określić źródła pochodzenia KŻ wykrywanych w tkankach mózgu i płynie mózgowo-rdzeniowym (QUINN i DEMORROW 2012). Obecnie przyjmuje się, że pochodzą one $z$ syntezy w układzie watrobowo-jelitowym i uwolnione do krażenia obwodowego przedostaja się przez barierę krew-mózg, jak opisano poniżej.

\section{TRANSPORT PRZEZ BARIERE KREW- MOZG}

Pierwotne i wtórne KŻ niesprzężone $Z$ aminokwasami (CA, CDCA, DCA, UDCA) moga przedostawać się przez barierę krew-mózg na zasadzie dyfuzji (KAMP i współaut. 1993). Sprzężone $z$ aminokwasami KŻ wymagaja aktywnego transportu ze względu na większą cząsteczkę, jej amfipatyczność i posiadanie ujemnego ładunku w fizjologicznym $\mathrm{pH}$ (CHOUdHURI i współaut. 2003). W badaniach $z$ użyciem modeli zwierzęcych oraz nielicznych $z$ użyciem materiału ludzkiego wykrywano obecność transporterów dla KŹ $z$ rodziny MRP i OATP (ang. organic anion-transporting polypeptide), BSEP, ASBT (ang. apical sodium-dependent bile acid transporter) w splocie naczyniówki. Ich ekspresja w OUN jest jednak wielokrotnie niższa niż w układzie wattrobowo-jelitowym (MERTENS i współaut. 2017). Wydaje się, że w warunkach fizjologicznych jedynie niewielka pula krażacych KŻ przedostaje się do mózgu. Natomiast w warunkach patologicznych, za niekontrolowanym napływem KŻ stoi uszkodzenie bariery krew-mózg (DEMORROW 2019).

\section{RECEPTORY KWASÓW ŻÓŁCIOWYCH}

Przez interakcje $z$ szeregiem systemów receptorowych KŻ pełnią funkcję molekuł bioracych udział w przekazywaniu sygnału. Największym zainteresowaniem badaczy cieszy się jądrowy receptor farnezoidowy $\mathrm{X}$ (FXR), który otrzymał nazwę od pierwszego opisanego liganda farnezolu (alkohol z grupy terpenów o intensywnym zapachu konwalii). Jego najsilniejszym aktywatorem jest CA (AHMAD i HAEUsLer 2019). Receptor FXR, po związaniu liganda, tworzy funkcjonalny heterodimer $z$ receptorem retinoidowym (RXR) i ten kompleks przyłącza się do dedykowanych sekwencji DNA w pro- 
motorach genów, wpływając na ich ekspresję (MASSAFRA i współaut. 2018). Sa to przede wszystkim geny kodujace enzymy biorace udział w regulacji homeostazy KZ̈. Aktywacja FXR zapewnia ujemne sprzężenie zwrotne syntezy KŻ, nie dopuszczając do nadmiernego wzrostu ich poziomu (FIORUCCI i współaut. 2007). Aktywacja receptora FXR moduluje ponadto wiele innych szlaków, m. in. szlak sygnałowy tlenku azotu (NO) w naczyniach, przez zwiększenie aktywności śródbłonkowej syntazy NO (eNOS) i przeciwdziała rozwojowi stanu zapalnego przez obniżanie ekspresji indukowalnej izoformy NOS i cyklooksygenazy 2 (COX-2) (Li i współaut. 2007, LI i współaut. 2008).

Drugim dobrze opisanym receptorem KŻ jest błonowy receptor sprzężony $z$ białkiem G, określany skrótem GPBAR1 lub TGR5, najsilniej aktywowany przez LCA (AHMAD i HAEUsler 2019). Pośredniczy w przekazywaniu sygnału poprzez KŻ, wpływając na produkcje cyklicznego monofosforanu adenozyny (cAMP) przez cyklazę adenylanowa, co prowadzi do aktywacji białek zależnych od cAMP, jak białkowa kinaza A (PKA), albo fosforylacji białka CREB (ang. cAMP response element binding protein) (HODGE i NUNEZ 2016, SCHONEwILle i współaut. 2016). Jego aktywacja bierze udział $\mathrm{w}$ regulacji metabolizmu energetycznego, rozkurczu i napełniania pęcherzyka żółciowego oraz wydzielania glukagonopodobnego peptydu 1 (ang. glucagon-like peptide 1, GLP-1) w jelitowych komórkach endokrynnych (MARTINOT i współaut. 2017).

Oba receptory znajduja się przede wszystkim w układzie watrobowojelitowym, ale stosunkowo niedawno kilka niezależnych badań potwierdziło ich obecność także w mózgu: FXR w neuronach (HuANG i współaut. 2016, MCMILLIN i współaut. 2016), TGR5 w neuronach i komórkach gleju (MARUYAMA i współaut. 2002, 2006; KeITEL i współaut. 2010; YANGUAS-CASÁS i współaut. 2017). Należy dodać, że poza tymi dwoma głównymi, jeszcze inne receptory znajdujące się w OUN maja potencjalna zdolność wiązania KŻ. Należa do nich m.in.: receptor pregnanu $\mathrm{X}$ (PXR), receptor witaminy D (VDR) czy receptor 1-fosforanu sfingozyny 2 (S1PR2) (MCMILLIN i DEMORROW 2016). W przeciwieństwie do receptorów FXR i TGR5, sa one dużo słabiej zbadane pod względem znaczenia ich aktywacji przez KŻ w OUN.

Poza receptorami, w mózgu potwierdzono obecność transporterów KŻ, m.in. ASBT w podwzgórzu i korze czołowej, co wskazuje na istnienie mechanizmu neuronalnego wy- chwytu KŻ (Mcmillin i współaut. 2015, NIZAMUTDINOV i współaut. 2017).

\section{DZIAŁANIE POŚREDNIE KWASÓW ŻÓECIOWYCH NA OUN}

Powyżej omówiono syntezę KŻ, ich receptory oraz sposoby jakimi moga się przedostać do mózgu lub zostać w nim wytworzone lokalnie. Nie należy jednak pominąć jeszcze innego ważnego aspektu działania KŻ. Moga one wywierać wpływ na OUN pośrednio za pośrednictwem osi jelito-mózg, bez działania lokalnego w mózgu i bez konieczności aktywacji swoistych receptorów dla KŻ w OUN. Stosunkowo dokładnie poznano dwie drogi i ich uproszczony przebieg zostanie przedstawiony poniżej.

Aktywacja FXR przez KŻ w jelicie powoduje uwalnianie czynnika wzrostu fibroblastów 19 (ang. fibroblast growth factor, FGF19) (HolT i współaut. 2003). Odpowiednikiem FGF19 u człowieka jest FGF15 u gryzoni (INAGAKI i współaut. 2005). Enterocyty uwalniaja FGF15/19 z ich błony podstawnej do żyły wrotnej, który następnie aktywuje receptor dla czynnika wzrostu fibroblastów (FGFR) 4 w wątrobie, co wtórnie hamuje syntezę de novo KŻ przez zahamowanie aktywności CYP7A1. Poza tym FGF15/19 jest zaangażowany $\mathrm{w}$ regulacje metabolizmu lipidów i glukozy. Zarówno u człowieka, jak i u myszy mRNA dla FGF15/19 znajdowano w dużej ilości w rozwijającym się mózgu, a nie było ono wykrywane u dorosłych osobników (NISHIMURA i współaut. 1999). Natomiast białko FGF19, obecne w krażeniu obwodowym, ma zdolność przedostania się przez barierę krew-mózg i, jak wykazano, jest względnie stabilne $\mathrm{w}$ mózgu (HsuCHOU i współaut. 2013), gdzie znajduja się receptory FGFR. Istotna rolę przy wiazaniu się czynnika FGF15/19 z jego receptorami odgrywa białko $\beta$-Klotho, pełniąc rolę kofaktora. Dotyczy to głównie rejonu podwzgórza, gdzie aktywacja FGFR bierze udział w kontroli zapotrzebowania energetycznego organizmu, metabolizmu glukozy i zapobieganiu otyłości (MERTENs i współaut. 2017).

Druga możliwością pośredniego działania KŻ w OUN jest szlak obejmujacy receptor TGR5 i glukagonopodobny peptyd 1 (GLP-1). Po aktywacji przez KZ̈ receptora TGR5 umiejscowionego na błonie podstawno-bocznej komórek L w jelicie następuje uwalnianie GLP-1, który wpływa na homeostazę energetyczna przez zmniejszenie apetytu i przyjmowania pokarmów oraz hamowanie opróżniania żołądka (DRUCKER i NAUCK 2006). Za produkcje GLP-1 odpowiedzialne sa komórki enteroendokrynne typu L, które znajdują się głównie w 


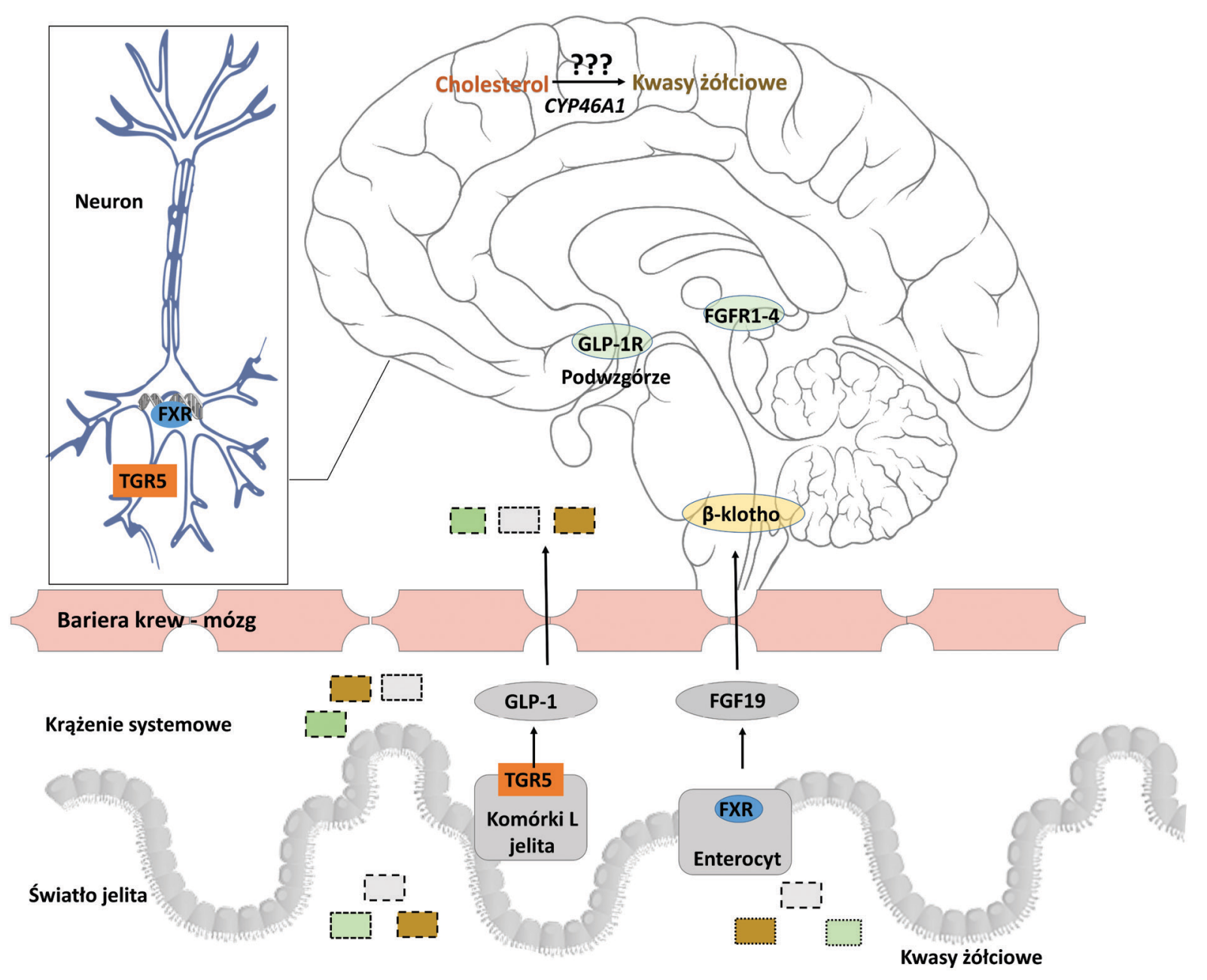

Ryc. 2. Punkty uchwytu dla kwasów żółciowych w OUN (opisane w tekście).

końcowej części jelita krętego i okrężnicy. GLP-1 może przedostać się $z$ krążenia obwodowego do mózgu i aktywować znajdujące się tam własne receptory (YAMAMOTO i współaut. 2003).

Potencjalne punkty uchwytu KŻ w mózgu zostały przedstawione na Ryc. 2.

\section{ZNACZENIE KŻ W SCHORZENIACH OUN}

Spośród schorzeń neurodegeneracyjnych, obecność KŻ w mózgu została najlepiej opisana w chorobie Alzheimera. W najnowszym doniesieniu przedstawiono pełen profil $\mathrm{KŻ} \mathrm{w}$ płynie mózgowo-rdzeniowym pacjentów udowadniajac, że ulega on znacznym zmianom w chorobie oraz różni się od profilu w surowicy (MAHMOUDIANDEHKORDI i współaut. 2019). To odkrycie sugeruje zarówno selektywność w transporcie KŻ przez bariere krew-mózg, jak i nie pozwala wykluczyć ich niezależnej syntezy w mózgu. Ponadto, coraz częściej postulowane jest znaczenie dysbiozy jelitowej w patogenezie chorób neurodegeneracyjnych (MAHMOUDIANDEHKORDI i współaut. 2019). Jako że KŻ ulegają modyfikacjom bakteryjnym w jelicie, jak i same wpływaja na mikrobiom, nie można wykluczyć, że odgrywaja one niebagatelna rolę $\mathrm{w}$ chorobach o podłożu neurodegeneracyjnym.

Szeroko udokumentowane znaczenie KŻ $\mathrm{w}$ encefalopatii watrobowej pozwala stwierdzić, że biora one udział $\mathrm{w}$ patogenezie tego schorzenia wpływajac na rozszczelnienie bariery krew-mózg (DEMORROW 2019). Wykazano również obniżona ekspresję receptora TGR5 w neuronach w warunkach hiperammonemii i ostrej encefalopatii wattrobowej oraz obniżenie stanu zapalnego $w$ OUN po podaniu agonisty TGR5 (KEITEL i współaut. 2010, MCMillin i współaut. 2015). Znaczenie aktywacji receptora FXR w mózgu nie zostało jeszcze w tej chorobie w pełni wyjaśnione, gdyż udokumentowano zarówno wzrost, jak i spadek jego ekspresji (MCMILLIN i współaut. 2016, CZARNECKA i ZIELIŃSKA 2018). 
Neuroprotekcyjne działanie wybranych KŻ udokumentowano dla szeregu chorób neurodegeneracyjnych, przede wszystkich w chorobie Alzheimera, Parkinsona, stwardnieniu zanikowym bocznym czy chorobie Huntingtona (ACKERMAN i GERHARD 2016), zarówno $\mathrm{w}$ badaniach in vitro, modelach zwierzęcych, jak i próbach klinicznych. Obserwowane efekty obejmowały zapobieganie akumulacji amyloidu beta, ochronę przed apoptoza, uszkodzeniem mitochondriów czy akumulacja ubikwityny (KIRIYAMA i NOCHI 2019).

Większość tych badań wykorzystywala kwas ursodeoksycholowy (UDCA), co bez watpienia ma zwiazek $z$ powszechnie utrwalonym przekonaniem o leczniczych własnościach tego KŻ, uniwersalnego leku starożytnej chińskiej medycyny ludowej, pozyskiwanego z żółci niedźwiedzia. Uogólniając, opisano podobny ochronny efekt kwasu tauroursodeoksycholowego (TUDCA) i UDCA w różnych chorobach neurodegeneracyjnych. Dokładny mechanizm, przez jaki wywieraja korzystne działanie, nie jest jednak znany. Postulowano ochronne działanie TUDCA i UDCA przed toksycznościa amyloidu beta $\mathrm{w}$ modelach in vitro choroby Alzheimera (SOLÁ i współaut. 2003). Mechanizm ochronny obejmowal regulacje $\mathrm{NFkB}$ i aktywacje szlaku PI3K (Joo i współaut. 2004). TUDCA wykazywał również działanie ochronne wobec toksyczności 1-metylo-4-fenylo-1,2,3,6-tetrahydropirydyny (MPTP) w modelach zwierzęcych choroby Parkinsona. Mechanizm ochronny obejmował obniżenie produkcji wolnych rodników (ROS) i zachowanie prawidłowego poziomu fosforylacji kinazy JNK (CASTRO-CALDAS i współaut. 2012). Dodatkowo wykazano, że aktywacja receptora TGR5 przez neurosteroidy może wywierać efekt przeciwzapalny (KARABABA i współaut. 2017). Ponadto wiadomo, że KŻ moduluja działanie receptorów dla wielu neuroprzekaźników, w tym receptory muskarynowe, receptory wiażace kwas $\gamma$-aminomasłowy (GABA) typu A oraz receptory N-metylo-D-asparaginowe (NMDA) (ACKERMAN i GERHARD 2016, KIRIYAMA i NoCHI 2019). Tą droga KŻ moga wpływać na funkcje poznawcze, pamięć i zdolności do uczenia się.

\section{PODSUMOWANIE}

Pomimo coraz większego zainteresowania KŻ jako cząsteczkami sygnałowymi, zrozumienie roli jaka odgrywaja one $\mathrm{i}$ ich receptory w OUN jest obecnie fragmentaryczne i wymaga dalszych badań. Wciaż nie można $z$ cała pewnościa wskazać źródła pochodzenia KŻ wykrywanych w tkankach mózgu i płynie mózgowo-rdzeniowym. Do pełnego opisania szlaków sygnałowych, w których re- gulacje sa zaangażowane KŻ i ich receptory w OUN brakuje nam wielu elementów. Bez wątpienia, nie można uznać efektów wywieranych przez różne typy KŻ za jeden spójny sygnał $\mathrm{w}$ OUN, co jest $\mathrm{m}$. in. zwiazane $z$ różnicami $\mathrm{w}$ ich powinowactwie do swoistych receptorów. Ponadto wydaje się, że należy całkowicie oddzielić efekty wywoływane przez $\mathrm{KŻ} \mathrm{w}$ warunkach ich patologicznego napływu do OUN od ich roli fizjologicznej, której towarzysza zmiany poziomów wywołane jedyne fluktuacjami w następstwie spożywanych posiłków. O regulacji tych mechanizmów w OUN ciagle wiemy bardzo niewiele.

Niezbędne jest dalsze, szczegółowe badanie i opisanie molekularnych mechanizmów neuroprotekcyjnego i toksycznego działania $\mathrm{KŻ} \mathrm{w} \mathrm{OUN,} \mathrm{aby} \mathrm{móc} \mathrm{ustalić} \mathrm{ich} \mathrm{faktycz-}$ ny potencjał terapeutyczny. Otwiera to niezmiernie interesująca niszę badań naukowych, zwłaszcza obecnie, w dobie ogromnego wzrostu zainteresowania znaczeniem osi jelito-mózg i jej wpływem na zdrowe życie.

Streszczenie

Kwasy żółciowe (KŻ) syntetyzowane $\mathrm{z}$ cholesterolu $\mathrm{w}$ watrobie sa przede wszystkim znane ze swojej roli w ułatwianiu trawienia i wchłaniania tłuszczów dostarczanych $z$ dieta. Jednak poza działaniem emulgujacym lipidy w układzie wątrobowo-jelitowym, KŻ sa czasteczkami sygnałowymi i posiadaja swoiste receptory rozmieszczone w różnych tkankach organizmu. Odkrycie ich obecności w mózgu wraz $\mathrm{z}$ doniesieniami o zdolności przedostawania się KŻ przez barierę krew-mózg zapoczątkowało badania nad znaczeniem sygnalizacji inicjowanej przez KŻ w ośrodkowym układzie nerwowym (OUN). Aktualnie dostępne doniesienia dotycza głównie chorób neurodegeneracyjnych oraz encefalopatii watrobowej, ale potencjalne znaczenie KŻ w OUN jest znacznie szersze. Niniejsza praca jest przegladem najnowszej literatury i ma na celu przybliżenie mechanizmów działania KŻ w mózgu oraz ukazanie ich jako potencjalnego celu nowych terapii schorzeń neurologicznych.

\section{LITERATURA}

ACKerman. H. D., Gerhard G. S., 2016. Bile acids in neurodegenerative disorders. Front. Aging Neurosci. 8, 263.

AHMAD T. R., HAEUSLER R. A., 2019. Bile acids in glucose metabolism and insulin signalling - mechanisms and research needs. Nat. Rev. Endocrinol. 15, 701-712.

BJÖRKHEM I., MEANEY S., 2004. Brain cholesterol: long secret life behind a barrier. Arterioscler. Thromb. Vasc. Biol. 24, 806-815.

BRON B., WALDRAM R., SILK D.B., Williams R., 1977. Serum, cerebrospinal fluid, and brain levels of bile acids in patients with fulminant hepatic failure. Gut 18, 692-696.

CASTRO-CALDAS M., CARVALHO A. N., RODRIGUES E., Henderson C. J,. Wolf C. R., Rodrigues C. M., GAMA M. J., 2012. Tauroursodeoxycholic acid prevents MPTP-induced dopaminergic cell death in a mouse model of Parkinson's disease. Mol. Neurobiol. 46, 475-486.

Choudhuri S., Cherrington N. J., Li N., KlaAssen C. D., 2003. Constitutive expression of various 
xenobiotic and endobiotic transporter mRNAs in the choroid plexus of rats. Drug Metab. Dispos. 31, 1337-1345.

CZARNECKA A., ZIELINSKA M., 2018. Farnesoid X receptor in the brain of rats with tioacetamide-induced acute liver failure. The 14th International Symposium: Molecular basis of pathology and therapy in neurological disorders. Folia Neuropathologica 56, 235-275.

De Aguiar Vallim T. Q., TARLing E. J., Edwards P. A., 2013. Pleiotropic roles of bile acids in metabolism. Cell Metab. 17, 657-669.

DEMORROW S., 2019. Bile acids in hepatic encephalopathy. J. Clin. Exp. Hepatol. 9, 117-124.

DRUCKER D. J., NAUCK M. A., 2006. The incretin system: glucagon-like peptide-1 receptor agonists and dipeptidyl peptidase-4 inhibitors in type 2 diabetes. Lancet 368, 1696-1705.

FIORUCCI S., RizzO G., DONINI A., DisTRUTTI E., SANTUCCI L., 2007. Targeting farnesoid $X$ receptor for liver and metabolic disorders. Trends Mol. Med. 13, 298-309.

HodGE R. J., NunEZ D. J., 2016. Therapeutic potential of Takeda-G-protein-receptor-5 (TGR5) agonists. Hope or hype? Diabetes Obes. Metab. 5, 439-443.

HOFMANN A. F., 2009. The enterohepatic circulation of bile acids in mammals: form and functions. Front. Biosci. 14, 2584-2598.

Holt J. A., LuO G., Billin A. N., Bisi J., MCNEIll Y. Y., KOZARSKY K. F., DONAHEE M., WANG D. Y., Mansfield T. A., KLIEWER S. A., GoOdWIN B., JoNES S. A., 2003. Definition of a novel growth factor-dependent signal cascade for the suppression of bile acid biosynthesis. Genes Dev. 17, 1581-1591.

Hsuchou H., PAN W., Kastin A. J., 2013. Fibroblast growth factor 19 entry into brain. Fluids Barriers CNS 10, 32.

Huang C., Wang J., Hu W., Wang C., LU X. TONG L., WU F., ZHANG W., 2016. Identification of functional farnesoid $X$ receptors in brain neurons. FEBS Lett. 590, 3233-3242.

Inagaki T., Choi M., Moschetta A., Peng L., Cummins C. L., Mcdonald J. G., LuO G., Jones S. A., GoOdwin B., Richardson J. A., GERARD R. D., REPA J. J., MANGELSDORF D. J., KLIEWER S. A., 2005. Fibroblast growth factor 15 functions as an enterohepatic signal to regulate bile acid homeostasis. Cell Metab. 2, 217-225.

Joo S. S., Won T. J., LEE D. I., 2004. Potential role of ursodeoxycholic acid in suppression of Nuclear factor kappa $B$ in microglial cell line (BV-2). Arch. Pharm. Res. 27, 954-960.

KamP F., Hamilton J. A., KAMP F., WESTERHOFF H. V., HAMILTON J. A., 1993. Movement of fatty acids, fatty acid analogs, and bile acids across phospholipid bilayers. Biochemistry 32, 11074-11085.

Karababa A., Groos-Sahr K., Albrecht U., Keitel V., SHAFIGUllinA A., GÖRG B., HÄUSSINGER D., 2017. Ammonia Attenuates LPS-Induced Upregulation of Pro- Inflammatory Cytokine mRNA in Co-Cultured Astrocytes and Microglia. Neurochem. Res. 42, 737-749.

KeITEl V., GÖRG B., BIDMON H. J., ZeMtsova I., SPOMER L., Zilles K., HÄUSSINGER D., 2010. The bile acid receptor TGR5 (Gpbar-1) acts as a neurosteroid receptor in brain. Glia 58, 1794-1805.

KIRIYAMA Y., NOCHI H., 2019. The biosynthesis, signaling, and neurological functions of bile acids. Biomolecules 9, 232.

Li J., Wilson A., KurubA R., ZHANG Q., GaO X., HE F., ZHANG L. M., PITT B. R., XIE W., LI S., 2008. FXR-mediated regulation of eNOS expression in vascular endothelial cells. Cardiovasc. Res. 77, 169-177.

Li Y. T., Swales K. E., Thomas G. J., Warner T. D., BISHOP-BAILEY D., 2007. Farnesoid $x$ receptor ligands inhibit vascular smooth muscle cell inflammation and migration. Arterioscler. Thromb. Vasc. Biol. 27, 2606-2611.

MaHMOUdiandeHKORDi S., ARNOLD M., NHO K., AHMAD S., JIA W. i współaut., 2019. Altered bile acid profile associates with cognitive impairment in Alzheimer's disease-An emerging role for gut microbiome. Alzheimers Dement. 15, 76-92.

Mano N., Goto T., UChida M., NishimURA K., Ando M., Kobayashi N., Goto J., 2004. Presence of protein-bound unconjugated bile acids in the cytoplasmic fraction of rat brain. J. Lipid Res. 45, 295-300.

MARTINOT E., SĖdes L., BAPTISSART M., LOBACCARO J. M., Caira F., Beaudoin C., Volle D. H., 2017. Bile acids and their receptors. Mol. Aspects Med. 56, 2-9.

MARUYAMA T., MIYAMOTO Y., NAKAMURA T., TAMAI Y., OKADA H., SUgIYAMA E., NAKAMURA T., ITADANI H., TANAKA K., 2002. Identification of membrane-type receptor for bile acids (M-BAR). Biochem. Biophys. Res. Commun. 298, 714719.

Maruyama T., TANaka K., Suzuki J., Miyoshi H., HARADA N., NAKAMURA T., MiYamOTO Y., KANATANI A., TAMAI Y., 2006. Targeted disruption of $G$ protein-coupled bile acid receptor 1 (Gpbar1/M-Bar) in mice. J. Endocrinol. 191, 197205.

Massafra V., Pellicciari R., Gioiello A., Van Mil S. W. C., 2018. Progress and challenges of selective Farnesoid $X$ Receptor modulation. Pharmacol. Ther. 191, 162-177.

MCMILlin M., DEMORROW S., 2016. Effects of bile acids on neurological function and disease. FASEB J. 30, 3658-3668.

MCMILLIN M., FRAMPTON G., TOBIN R., Dusio G., Smith J., Shin H., NEwell-Rogers K., GRANT S., DEMORROW S., 2015. TGR5 signaling reduces neuroinflammation during hepatic encephalopathy. J. Neurochem. 135, 565-576.

MCMILlin M., FRAMPTON G., QUINN M., AshFaQ S., De Los Santos M $3^{\mathrm{RD}}$., Grant S., DEMORROW S., 2016. Bile acid signaling is involved in the neurological decline in a murine model of acute liver failure. Am. J. Pathol. 186, 312-323.

MeRTENS K. L., KALSBEEK A., Soeters M. R., EGGINK H. M., 2017. Bile acid signaling pathways from the enterohepatic circulation to the central nervous system. Front. Neurosci. 11, 617.

NishimURA T., UtSUNOMIYA Y., HoshiKaWA M., OHUCHI H., ITOH N., 1999. Structure and expression of a novel human FGF, FGF-19, expressed in the fetal brain. Biochim. Biophys. Acta 1444, 148-151.

Nizamutdinov D., DemorRow S., MCMillin M., KAIN J., MUKHERJEE S., ZEITOUNI S., FRAMPTON G., BRICKER P. C., HURST J., SHAPIRO L. A., 2017. Hepatic alterations are accompanied by changes to bile acid transporter-expressing neurons in the hypothalamus after traumatic brain injury. Sci. Rep. 7, 40112.

NORLIN M., TOLL A., BJÖRKHEM I., Wikvall K., 2000. 24-Hydroxycholesterol is a substrate for hepatic cholesterol 7a-hydroxylase (CYP7A). J. Lipid Res. 41, 1629-1639.

Pan X., ElliotT C. T., McGuinness B., Passmore P., Kehoe P. G., Hölscher C., Mcclean P. L., GRAHAM S. F., GREEN B. D., 2017. Metabolomic profiling of bile acids in clinical and expe- 
rimental samples of Alzheimer's disease. Metabolites 7,28 .

QUINN M., DEMORROW S., 2012. Bile in the brain? A role for bile acids in the central nervous system. J. Cell Sci. Ther. 3, 7.

QUiNN M., MCMILlin M., GALINDO C., FRAMPTON G., PAE H. Y., Demorrow S., 2014. Bile acids permeabilize the blood brain barrier after bile duct ligation in rats via Rac1-dependent mechanisms. Dig. Liver Dis. 46, 527-534.

SChONEWIlle M., DE BOER J. F., GROEN A. K. 2016. Bile salts in control of lipid metabolism. Curr. Opin. Lipidol. 27, 295-301.

Solá S., Castro R. E., Laires P. A., Steer C. J., RoDRIGUES C. M., 2003. Tauroursodeoxycholic acid prevents amyloid-beta peptide-induced neuronal death via a phosphatidylinositol 3-kinase-dependent signaling pathway. Mol. Med. 9, 226-234.

Tripodi V., CONTIN M., FERnÁndeZ M. A., LEMBERG A., 2012. Bile acids content in brain of common duct ligated rats. Ann. Hepatol. 11, 930934.

Weiss N., Barbier Saint Hilaire P., COlsch B., ISNARD F., ATTALA S., SCHAEFER A., AMADOR M. D., Rudler M., LAMARI F., Sedel F., Thabut D., JunOT C., 2016. Cerebrospinal fluid metabolomics highlights dysregulation of energy metabolism in overt hepatic encephalopathy. J. Hepatol. 65, 1120-1130.

WiEland H. O., 1928. Nobel Lectures, Chemistry 1922-1941. The chemistry of the bile acids. www.nobelprize.org/prizes / chemistry/1927/ wieland/lecture/.

Yamamoto H., Kishi T., Lee C. E., Choi B. J., FANG H., Hollenberg A. N., DRUCKer D. J., ELMQUIST J. K., 2003. Glucagon-like peptide-1-responsive catecholamine neurons in the area postrema link peripheral glucagon-like peptide-1 with central autonomic control sites. J. Neurosci. 23, 2939-2946.

YANGUAS-CASÁS N., BARREDA-MANSO M. A., NIETO-SAMPEDRO M., ROMERO-RAMÍREZ L., 2017. TUDCA: An Agonist of the Bile Acid Receptor GPBAR1/TGR5 With Anti-Inflammatory Effects in Microglial Cells. J. Cell Physiol. 232, 22312245.

ZHANG J., LIU Q., 2015. Cholesterol metabolism and homeostasis in the brain. Protein Cell 6, 254-264.

Zheng X., Chen T., Zhao A., Wang X., Xie G., Huang F., LiU J., ZHAO Q., WANG S., WANG C., ZHou M., PANEe J., HE Z., JiA W., 2016. The brain metabolome of male rats across the lifespan. Sci. Rep. 6, 24125.

KOSMOS Vol. 69, 1, 37-44, 2020

AnNa CZaRnecka, Magdalena ZielińsKa

Department of Neurotoxicology, Mossakowski Medical Research Centre PAS, 5 Pawińskiego Str., 02-106 Warszawa, E-mail: aczarnecka@imdik.pan.pl

WHY DO WE NEED BILE ACIDS IN THE BRAIN?

Summary

Bile acids (BAs) synthesized from cholesterol in the liver are classically known for their roles in facilitating the digestion and absorption of dietary lipids. However, in addition to the lipid emulsifying role in the gastrointestinal tract, BAs have been described as signaling molecules acting through multiple receptors localized in various tissues of the body. The discovery of BAs receptors in the brain, concomitantly with reports of the ability of BAs to cross the blood-brain barrier, has initiated studies on the significance of BAs signaling in the central nervous system (CNS). Current research is mainly focused on neurodegenerative disorders and hepatic encephalopathy but the potential significance of BAs in the CNS is much broader. The review will deal with a brief description of BAs mechanisms of action in the brain as well as their role as a potential target for new therapies of neurological diseases.

Key words: bile acids, blood-brain barrier, cholesterol, enterohepatic circulation, hepatic encephalopathy, neurodegenerative diseases, neuron 